The Impact of Equity Incentives on the Accuracy of Analyst's Earning Forecasts

Dr/ Samar Mansour Elsebaai Mohamed Moubarak

\title{
The Impact of Equity Incentives on the Accuracy of Analyst's Earning Forecasts
}

\section{Samar Mansour Elsebaai Mohamed Moubarak}

\begin{abstract}
:
This study use a sample which consists of 88 observations of Egyptian listed firms, from the period of 2009 - 2019, this research examine the effect of equity incentive types on the information and knowledge environment of financial analysts, as expressed in the reports of analysts in the form of earning forecasts and stock recommendations. In addition, analysts' forecast accuracy can be improved when companies prefer and select using restricted stock units (RSUs) as a type of reward managers, instead of stock options, in their reward program, assuming that the two forms of stock compensations (stock options or RSUs) have different and significant impacts on the accuracy of analysts' forecasts. Finally findings revealed positive relationship between forecast accuracy and recommendations as financial analysts serve as information intermediaries by providing reports that include earnings forecasts and their stock recommendations. These recommendations help investors to make their decisions.
\end{abstract}

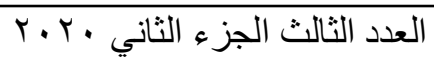

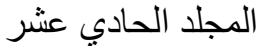


The Impact of Equity Incentives on the Accuracy of Analyst's Earning Forecasts

Dr/ Samar Mansour Elsebaai Mohamed Moubarak

Keywords: Stock options; restricted stock units; analysts' earnings forecasts; stock recommendations

\section{Introduction and research problem:}

In recent decades, there are many developments on the economic, social or political level. Executive compensation has been the most important issue facing companies in recent years. Firms offer stock incentives in the form of restricted stock and stock options to enable managers to make decisions that favor shareholders. Both stock options and restricted stock units help to alleviate agency problems that results from the separation of ownership and control in companies. Stock options are becoming a greater part of executive compensation over the past decade. Recently, the incentive for companies in the stock market has shifted dramatically from stock option grants to restricted stock grants (Abudy and Benninga, 2016). Financial analysts help investors to make stock investment decisions by issuing earnings forecasts and stock recommendations to the market. This research therefore seeks to show a discussion and analysis of how the information that equity-compensated managers provide enhance firms' information environment for financial analysts. This means that equity incentives affect future earnings forecasts and financial analysts can affect investment behavior.

$$
\text { العدد الثالث الجزء الثاني · r r r }
$$

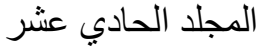


The Impact of Equity Incentives on the Accuracy of Analyst's Earning Forecasts

Dr/ Samar Mansour Elsebaai Mohamed Moubarak

Although stock options are the most widely used type of equity compensation, it seems to be less desirable for managers, so companies have begun to grant employees and managers restricted stock units instead of granting stock options as a highly motivating method. Both types of equity compensation types (stock options and restricted stock units) have various effects on the accuracy of analysts' forecasts. These types motivate managers to increase the transparency of corporate information that can reflected on earnings forecasts accuracy.

This study reveals that the accuracy of analysts' earnings forecasts is improved by enhancing the relationship between financial analysts and management of the company as the management is considered one of the most significant sources of collecting essential data for an analyst. Equity incentive system is a type of Management compensation system affects forecasts of financial earnings because it can improve and provide better environment for financial analysts.

\section{2- Literature Review and Hypothesis Development:}

This chapter aims to discuss the previous studies that analyze the relationship between equity incentives and the accuracy of analyst's earnings forecasts and their effect on analyst's stock recommendations.

$$
\text { r. r. • العدد الثالث الجزء الثاني }
$$

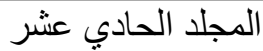


The Impact of Equity Incentives on the Accuracy of Analyst's Earning Forecasts

Dr/ Samar Mansour Elsebaai Mohamed Moubarak

Recently, executive pay has become the most controversial issue that faces corporations. Executive compensation include mix of various components; some are paid in cash such as base salary and short-term bonus and others non-cash compensation as it paid in form of shares such as long term incentives or equity based rewards such as stock options or restricted stock units.

(Choi and Kim, 2016) investigate whether the market able to estimate future earnings affected by stock compensation. The market can't expect future performance managers attempt to manipulate the stock price to increase their own benefit instead of the benefit of shareholders. Their results indicate that more information about current stock prices affect on future earnings. In addition, they found that the positive effect is weaker for firms that have low management forecast frequency.

Other researches focus on the association between equity compensation and accuracy of financial analyst's as security analysts play informational role for in providing stock recommendations in emerging markets. There are prior literature insights into the Substantial effect of the equity compensation management as a one of the major source of information that analysts need. For example (Liu, 2018) This study examine how can equity compensation policy enhance the information environment of financial analysts that affect on the analysts'

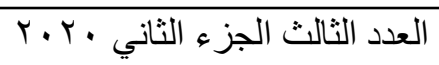

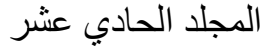


The Impact of Equity Incentives on the Accuracy of Analyst's Earning Forecasts

Dr/ Samar Mansour Elsebaai Mohamed Moubarak

outputs that include analyst's earnings forecasts and their stock recommendations.

Additionally (Han, et al., 2014) examines the association between managerial stock ownership and the information environment of financial analyst's. Managers' stock ownership help to match between manger's interest shareholder's interests. Managers' behavior impact on the information environment of the company in different manners. Such as providing more comprehensive and accurate financial information, this results enhancing public disclosure quality. They can also voluntarily provide incremental information to investors in the market through forecasts made by managers.

(Jiang, et al., 2017) examine how equity incentives promote disclosure management, decrease information asymmetry, and alleviate opportunistic behavior to secure their compensation pay. They found that if firms have compensation committees, stock options can be granted to motivate and incentive managers. Also (Fang, et al., 2015) illustrates the effect of their equity incentive policy on firm's performance by comparing companies that granted with stock options with similar companies not granted with options.

In addition in recent years, there has been a significant shift in equity-based compensation from employee stock options (ESOs)

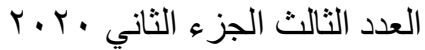

المجلد الحادي عشر 
The Impact of Equity Incentives on the Accuracy of Analyst's Earning Forecasts

Dr/ Samar Mansour Elsebaai Mohamed Moubarak

towards restricted stock (RS) compensation. Previous studies such as (Abudy and Benninga, 2016) examine the differential effect between stock options and restricted stock as different types of equity incentives. Restricted stocks are additional form of equity based compensation. This compensation form, the employee is granted with either right to receive stocks once the vesting requirements are met or with stocks which are restricted until the vesting requirements are met. These compensation forms are called restricted stocks units and restricted stock. The key variance is that RSU policies deliver the stocks to the employee only after the vesting period while RS programs deliver the (restricted) stocks at the grant date. Thus, RSU holders have no voting rights and usually are not entitled to receive dividend.

Other researches focus on the shift in equity-based compensation as stock options become less attractive to managers, so some firms have started to issue restricted stock units as the alternative of stock options and consider better motivating tool. For example, (Tai ,2017) Investigate a dramatic change in compensation system from stock option to restricted stock. This study also shows that the restricted stock grants companies used as a less costly type to match the interests of employees with those of shareholders. Restricted stock grants reduce the variance of cost-value.

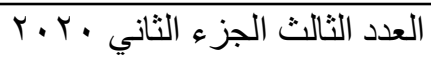

المجلد الحادي عشر 
The Impact of Equity Incentives on the Accuracy of Analyst's Earning Forecasts

Dr/ Samar Mansour Elsebaai Mohamed Moubarak

It can be concluded from above mentioned literature that the application of managerial stock ownership improve financial analysts' information environment, as managers' stock ownership better aligns their interest with the interests of shareholders. Additionally, Manager's actions impact a firm's information environment in a variety of ways. For example, they can improve public disclosure quality by providing more comprehensive and accurate financial information.

Previous studies summarize the relationships between equity incentives as one type of executive compensation and how these incentives can affect analyst's earnings forecasts. This study also shows that restricted stock units provide more accuracy of financial analyst's forecasts than stock options, this regarding to several reasons:

First: stock options may become worthless in market downturn (when market price less than exercise price).

Second: the grant price for restricted stock units is zero so it is less risky and it is granted instead of specific requirements, thus employee continue with the company for number of years, this can help the firm to achieve targets such as earning per share and sales volume.

Third: when restricted stock units are vested, managers who receive RSUs becomes owners of the company, unlike stock options have little ownership.

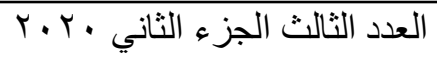$$
\text { المجلد الحادي عشر }
$$ 
The Impact of Equity Incentives on the Accuracy of Analyst's Earning Forecasts

Dr/ Samar Mansour Elsebaai Mohamed Moubarak

For these reasons, stock options become less attractive to managers, so some firms have begun to issue and grant restricted stock units as alternative method instead of stock options and is considered better motivating tool.

\section{3- Research method}

Using the mentioned sample, first the researcher conduct univariate analysis for preliminary examination of the full sample. The researcher will conduct descriptive analysis including minimum, maximum, mean, median and standard deviation for the variables of the study. Second, the researcher will use Pearson's correlation analysis to check for multicollinearity and whether they provide any preliminary evidence in support of my predictions for research hypothesis. Third, this study use multiple regression models to test my hypothesis and ensuring that the data not having a problem with Linearity, multicollinearity, autocorrelation, and heteroscedasticity.

This study uses such as SPSS V 25, STATA V 16, and AMOS 25 statistical program to merge the tables of data of different databases and for running the regression model. In addition, this study uses SPSS statistical program.

$$
\text { العدد الثالث الجزء الثاني • r r r }
$$

المجلد الحادي عثر 
The Impact of Equity Incentives on the Accuracy of Analyst's Earning Forecasts

Dr/ Samar Mansour Elsebaai Mohamed Moubarak

\section{1 sample construction}

In this section, the researcher describes the method and steps that are followed to construct the final sample used in the regression analysis.

\subsection{Data Sources}

This study uses Egyptian listed companies during 2009 to 2019 as analysis sample. Sample is international and multinational companies that have data used in this study. Some financial and accounting information data are extracted from the Egyptian Stock Market, Accounting Research database and Egypt for Information Dissemination (EGID).

\subsection{Variables and Measures:}

This section describes the variables of the model including dependent, independent, and control variables. Multiple regression models are employed to examine the impact of Equity incentive plans on the accuracy of analysts' earnings forecasts. .

\subsubsection{Dependent Variable}

(a) The accuracy of analyst's earnings forecasts

The dependent variable is the accuracy of analyst's earnings forecasts. The researcher follow the model (Kanagaretnam, et al., 2012) to measure forecast accuracy, which can be measured as minus one times the absolute value of the deviation of the mean EPS forecast from the actual EPS for that year divided by stock price at the forecast date. This measure increases with forecast accuracy.

$$
\text { المجل الحادي عشر }
$$


The Impact of Equity Incentives on the Accuracy of Analyst's Earning Forecasts

Dr/ Samar Mansour Elsebaai Mohamed Moubarak

$$
\left.\operatorname{ACCURACY~it~}=(-1) * \frac{\left.\mid \text { FEPS }_{\mathrm{I}, \mathrm{t}-1}-\text { AEPS }_{\mathrm{i}, \mathrm{t}-1}\right\rfloor}{\mathrm{P}_{\mathrm{i}, \mathrm{t}-1}}\right\rfloor
$$

where, for firm i, ACCURACYt is minus one times the absolute forecast error at time $t$, FEPS $t \mathrm{t}-1$ the mean EPS forecast from Egyptian companies for year $\mathrm{t}$ made at time $\mathrm{t}$ 1 , AEPSt is the actual earnings per share and Pt-1 is the stock price at a specific date.

The researcher also can measure the accuracy of earnings forecasts by calculating absolute forecast error (Bias). Bias is the deviation degree of analysts' earnings forecasts. In order to measure the accuracy of earnings forecasts, the researcher use the deviation degree of analysts' earnings forecasts, which is calculated as the following Equation

$$
\text { Bias }=\underline{\text { FEPS }}_{i, t-1}-\text { AEPS }_{i, t-1}
$$

FEPS $_{\mathrm{i}, \mathrm{t}}$

$F E P S_{\mathrm{I}} \mathrm{t}-1=$ the mean earnings per share $(\mathrm{EPS})$ forecast one year ahead for year

$A E P S_{\mathrm{I}} \mathrm{t}=$ the actual EPS for year $\mathrm{t}$;

$F E P S_{I}, t=$ forecasted earnings per share for the year $\mathrm{t}$.

Lower value in Bias means that there is lower level of errors in analysts' earnings forecasts, which means the higher analysts' earnings forecasts accuracy.

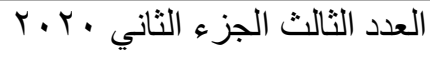$$
\text { المجلد الحادي عثر }
$$ 
The Impact of Equity Incentives on the Accuracy of Analyst's Earning Forecasts

Dr/ Samar Mansour Elsebaai Mohamed Moubarak

Analysts are evaluated based on multiple criteria such as stock picking ability, earnings forecast accuracy, quality of written reports, and overall service methodology adopts a firm-year perspective. For each firm-year. The researcher sort analysts into quintiles based on the accuracy of their forecasts of annual earnings.

\section{2- Independent variable}

\section{- CEO options (OPTIONS)}

The level of CEO options pay (OPTIONS) as the ratio of the number of options to total number of shares outstanding. This is consistent with the measure. It is a simple variable that measures the relative proportion of stock options in a CEO's compensation for a particular year.

\subsubsection{Restricted stock units}

The level of restricted stock units measured as the ratio of the number of restricted stock units to total number of shares outstanding.

\subsubsection{Control Variables:}

In the statistical tests the researcher control for previously identified determinants of forecast accuracy. The researcher identifies different factors that may affect on forecast accuracy. These include earnings characteristics, firm characteristics and forecast characteristics.

$$
\text { العدد الثالث الجزء الثاني • r r r }
$$$$
\text { المجلد الحادي عشر }
$$ 
The Impact of Equity Incentives on the Accuracy of Analyst's Earning Forecasts

Dr/ Samar Mansour Elsebaai Mohamed Moubarak

(a) Earnings characteristics

- (VOLROA) is a control variable, reflecting earning volatility of the listed company, the researcher measure earning volatility (VOLROA) as the standard deviation of return on assets estimated using data from the financial reports of international companies .

- accounting loss (LOSS) is an indicator variable representing firm-years with reported losses and the researcher obtain this data from financial statements of companies.

- Earning surprise (ABSESUP): A deviation of the analyst's own earnings forecast from the consensus forecast represents the analyst's implicit prediction of a future earnings surprise). It can be measured as the absolute value of the difference between the current year's EPS and the previous year's EPS, divided by stock price at the beginning of the year.

\section{(b) Firm characteristics}

It includes firm size, growth (which consider an important driver of forecast complexity) and governance variables that considered as firm-specific control variables that are likely to be related to forecast accuracy. The researcher in this study use firm size and measure (SIZE) as the natural log of total assets (Ou, 2017).

\section{(c) Forecast characteristics}

Prior research has identified two forecast characteristics that are related to forecast accuracy which are number of analysts following a firm and dispersion in analysts' forecasts.

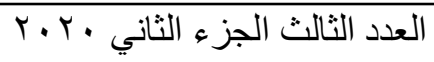$$
\text { المجلد الحادي عثر }
$$ 
The Impact of Equity Incentives on the Accuracy of Analyst's Earning Forecasts

Dr/ Samar Mansour Elsebaai Mohamed Moubarak

Forecast dispersion may be used as proxy for the degree of difficulty in forecasting earnings. With high analysts' forecast dispersion firms exhibiting lower levels of earnings predictability. Therefore, the researcher also expects forecast dispersion to be negatively related to forecast Accuracy. It can be measured as the standard deviation of all EPS forecasts for the year divided by the stock price at the beginning of the year).

\subsection{Research Model specification for hypothesis testing:}

This study uses regression and multiple regression models to determine the association between equity compensation and accuracy of analyst's earnings forecasts.

\section{Sample description:}

The study population consists of companies that have the characteristics required to be studied, the number of (8) companies and the number of observations (88) as in the following table:

Table (1) Sample Distribution Procedures

\begin{tabular}{|l|c|c|c|}
\hline \multicolumn{1}{|c|}{ Companies } & $\begin{array}{c}\text { Before } \\
\text { observation }\end{array}$ & $\begin{array}{c}\text { After } \\
\text { Observation }\end{array}$ & \\
\hline Elswedy corporation & $\mathbf{1 1}$ & $\mathbf{9}$ & $\mathbf{1 2 . 9 \%}$ \\
\hline Vodafone corporation & $\mathbf{1 1}$ & $\mathbf{9}$ & $\mathbf{1 2 . 9 \%}$ \\
\hline CIP & 11 & 9 & $\mathbf{1 2 . 9 \%}$ \\
\hline Pepsi Corporation & 11 & 9 & $\mathbf{1 2 . 9 \%}$ \\
\hline $\begin{array}{l}\text { Transglope } \\
\text { corporation }\end{array}$ & 11 & $\mathbf{8}$ & $\mathbf{1 1 . 4 \%}$ \\
\hline
\end{tabular}

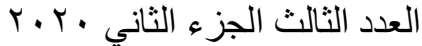

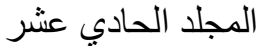


The Impact of Equity Incentives on the Accuracy of Analyst's Earning Forecasts

Dr/ Samar Mansour Elsebaai Mohamed Moubarak

\begin{tabular}{|l|c|c|c|}
\hline Raya Corporation & 11 & 9 & $12.9 \%$ \\
\hline GB Motors & 11 & 10 & $14.1 \%$ \\
\hline Ezz steal & 11 & 7 & $10 \%$ \\
\hline \multicolumn{1}{|c|}{ Total } & 88 & 70 & $100 \%$ \\
\hline
\end{tabular}

Table (2) Final sample for Companies

\begin{tabular}{|l|c|}
\hline \multicolumn{1}{|c|}{ Study procedures } & Observation \\
\hline Population Study & $\mathbf{8 8}$ \\
\hline (-) Missing Data & $\mathbf{5}$ \\
\hline (-) Outliers value & $\mathbf{1 3}$ \\
\hline
\end{tabular}

\section{Study variables and how to measure them :}

The researcher can clarify the study variables in the following table:

Table (3) Research Variables and how to measure them

\begin{tabular}{|c|c|c|c|c|}
\hline \multirow[t]{2}{*}{$\mathbf{N}$. } & \multicolumn{2}{|c|}{ Study Variables } & \multirow[t]{2}{*}{ How to measure them } & \multirow{2}{*}{$\begin{array}{l}\text { Stat. } \\
\text { code }\end{array}$} \\
\hline & Variables & Types & & \\
\hline 1 & CEO options & Independent & $\begin{array}{l}\text { the ratio of the number of } \\
\text { options to total number of } \\
\text { shares outstanding }\end{array}$ & SO \\
\hline 2 & $\begin{array}{l}\text { Restricted } \\
\text { stock units }\end{array}$ & Independent & $\begin{array}{l}\text { Measured as the ratio of the } \\
\text { number of restricted stock } \\
\text { units to total number of } \\
\text { shares outstanding. }\end{array}$ & (RSU) \\
\hline 3 & $\begin{array}{l}\text { Accuracy } \\
\text { of earning } \\
\text { forecast }\end{array}$ & Dependent & $\begin{array}{l}\text { ACCURACY }_{\mathrm{it}}=(-1) * \\
\left.\mid \text { FEPS }_{\mathrm{i}, \mathrm{t}-1}-\text { AEPS }_{\mathrm{i}, \mathrm{t}}\right\rfloor \\
\mathrm{P}_{\mathrm{i}, \mathrm{t}-1} \\
\text { BIAS }= \\
\frac{\left.\mid \text { FEPS }_{\mathrm{i}, \mathrm{t}-1}-\text { AEPS }_{\mathrm{i}, \mathrm{t}}\right\rfloor}{\text { FEPS }_{\mathrm{i}, \mathrm{t}}}\end{array}$ & (FACC) \\
\hline
\end{tabular}

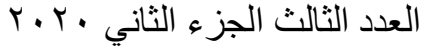

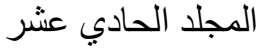


The Impact of Equity Incentives on the Accuracy of Analyst's Earning Forecasts

Dr/ Samar Mansour Elsebaai Mohamed Moubarak

\begin{tabular}{|c|c|c|c|c|}
\hline \multicolumn{5}{|c|}{ Table (4) Control Variables and how to measure them } \\
\hline \multirow[t]{2}{*}{ N. } & \multicolumn{2}{|c|}{ Study Variables } & \multirow[t]{2}{*}{ How to measure them } & \multirow{2}{*}{$\begin{array}{l}\text { Stat. } \\
\text { code }\end{array}$} \\
\hline & Variables & Types & & \\
\hline 4 & $\begin{array}{l}\text { Earning } \\
\text { volatility }\end{array}$ & $\begin{array}{l}\text { Control } \\
\text { variable }\end{array}$ & S.D. Return of assets & (VOLROA) \\
\hline 5 & Firm Size & $\begin{array}{l}\text { Control } \\
\text { variable }\end{array}$ & Log. Of beg Assets & (SIZE) \\
\hline 6 & $\begin{array}{l}\text { Accounting } \\
\text { Loss }\end{array}$ & $\begin{array}{l}\text { Control } \\
\text { variable }\end{array}$ & Financial data & (LOSS) \\
\hline 7 & $\begin{array}{l}\text { Absolute } \\
\text { earning } \\
\text { surprise }\end{array}$ & $\begin{array}{l}\text { Control } \\
\text { variable }\end{array}$ & $\begin{array}{l}\text { Measured as the absolute } \\
\text { value of the difference } \\
\text { between the current } \\
\text { year's EPS and the } \\
\text { previous year's EPS, } \\
\text { divided by stock price at } \\
\text { the beginning of the year }\end{array}$ & (ABSEUP) \\
\hline 8 & Depression & $\begin{array}{l}\text { Control } \\
\text { variable }\end{array}$ & $\frac{\text { Forecasted EPS }}{\text { Stock price at the Beg }}$ & (DISP) \\
\hline
\end{tabular}

\subsection{Data Analysis and Results:}

Hypothesis analysis will be divided into two phases:

The first stage: descriptive analysis of the data with statistical analysis methods:

\subsubsection{Descriptive Analysis :}

The results of the descriptive analysis reached Table (3), which shows the mean and the standard deviation of the data, as follows:

$$
\text { العدد الثالث الجزء الثاني • r. r }
$$$$
\text { المجلد الحادي عشر }
$$ 
The Impact of Equity Incentives on the Accuracy of Analyst's Earning Forecasts

Dr/ Samar Mansour Elsebaai Mohamed Moubarak

Table (5) Descriptive Analysis

\begin{tabular}{|l|c|c|c|c|c|c|}
\hline Variables & Obs. & Mean & S.D & Median & Max. & Min. \\
\hline CEO & $\mathbf{7 0}$ & 0.2243 & 0.3625 & 0.113 & 13134 & 0.00 \\
\hline RSU & $\mathbf{7 0}$ & 0.4286 & 0.4984 & 0.136 & 1 & 0 \\
\hline VOLROA & $\mathbf{7 0}$ & 3.69 & 7.77 & 1.223 & 27.34 & -24.03 \\
\hline SIZE & $\mathbf{7 0}$ & 7,82 & 1,24 & 3.654 & 64865 & -7644 \\
\hline LOSS & $\mathbf{7 0}$ & 5.93 & 3.40 & 1.350 & 10.72 & 0 \\
\hline ABSEUP & $\mathbf{7 0}$ & 0.147 & 0.328 & 0.117 & 1.11 & -0.51 \\
\hline DISP & $\mathbf{7 0}$ & 0.092 & 0.201 & .007 & 1 & 0 \\
\hline \multicolumn{1}{|c|}{ BIAS } & $\mathbf{7 0}$ & 0.230 & 0.260 & .017 & 1 & 0 \\
\hline ACCURACY & $\mathbf{7 0}$ & 0.210 & 0.117 & 0.015 & 1 & 0 \\
\hline
\end{tabular}

Table (6) Normal Distribution

\begin{tabular}{|l|c|c|c|c|c|c|}
\hline \multirow{2}{*}{ Variables } & \multicolumn{2}{|c|}{ Kolmogorov-Smirnov } & \multicolumn{3}{c|}{ Shapiro-Wilk } \\
\cline { 2 - 7 } & Statistics & d.f. & Sig. & Statistics & d.f. & Sig. \\
\hline CEO & 0.321 & 70 & 0,000 & 0.726 & 70 & 0,000 \\
\hline RSU & 0.351 & 70 & 0,000 & 0.636 & 70 & 0,000 \\
\hline VOLROA & 0.172 & 70 & 0.005 & 0.889 & 70 & 0.001 \\
\hline SIZE & 0.405 & 70 & 0,000 & 0.479 & 70 & 0,000 \\
\hline LOSS & 0.207 & 70 & 0,000 & 0.822 & 70 & 0,000 \\
\hline ABSEUP & 0.338 & 70 & 0,000 & 0.759 & 70 & 0,000 \\
\hline DISP & 0.372 & 70 & 0,000 & 0.475 & 70 & 0,000 \\
\hline \multicolumn{1}{|c|}{ BIAS } & 0.153 & 70 & 0.019 & 0.896 & 70 & 0.001 \\
\hline
\end{tabular}

It is clear from the previous table that all the values related to the variables were significant at the level of $5 \%$, where the values

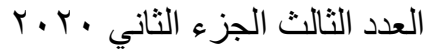

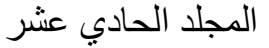


The Impact of Equity Incentives on the Accuracy of Analyst's Earning Forecasts Dr/ Samar Mansour Elsebaai Mohamed Moubarak

were less than the level of significance, which indicates the need to use Non - Parametric Methods when examining the hypotheses of the study.

\subsection{2 inferential statistics :}

The researcher can use a set of statistical analysis methods to test the hypotheses of the study, such as correlation coefficients to clarify the relationship between variables, in addition to using regression analysis methods, as follows:

Table (7) Pearson Correlation Matrix ( $\mathbf{N}=70)$

\begin{tabular}{|c|c|c|c|c|c|c|c|c|c|}
\hline & & $\mathbf{O P}$ & $\mathbf{R S U}$ & VOLROA & SIZE & LOSS & ABSEUP & DISP & BIAS \\
\hline \multirow[t]{2}{*}{ CEO } & Correlation Coefficient & 1.00 & & & & & & & \\
\hline & Sig & & & & & & & & \\
\hline \multirow[t]{2}{*}{ RSU } & Correlation Coefficient & $0.144 * *$ & 1.00 & & & & & & \\
\hline & Sig & 0.001 & & & & & & & \\
\hline \multirow[t]{2}{*}{ VOLROA } & Correlation Coefficient & 0.061 & $0.256 *$ & 1.00 & & & & & \\
\hline & Sig & 0.645 & 0.047 & & & & & & \\
\hline \multirow{2}{*}{ SIZE } & Correlation Coefficient & 0.298* & 0.333* & 0.535 ** & 1.00 & & & & \\
\hline & Sig & 0.047 & 0.025 & 0.000 & & & & & \\
\hline \multirow[t]{2}{*}{ LOSS } & Correlation Coefficient & 0.288* & 0.313* & 0.173* & $0.428 * *$ & \multirow[t]{2}{*}{1.00} & & & \\
\hline & Sig & 0.026 & 0.015 & 0.029 & 0.004 & & & & \\
\hline \multirow[t]{2}{*}{ ABSEUP } & Correlation Coefficient & 0.201 & .109 & 0.240 & 0.304* & 0.202* & 1.00 & & \\
\hline & Sig & 0.129 & 0.416 & 0.022 & 0.053 & \begin{tabular}{|l|}
0.035 \\
\end{tabular} & & & \\
\hline \multirow[t]{2}{*}{ DISP } & Correlation Coefficient & 0.087 & 0.154 & 0.117* & 0.124* & $0.257 *$ & 0.148* & \multirow[t]{2}{*}{1.00} & \\
\hline & Sig & 0.472 & 0.202 & .028 & 0.034 & \begin{tabular}{|l|}
0.047 \\
\end{tabular} & 0.007 & & \\
\hline \multirow[t]{2}{*}{ BIAS } & Correlation Coefficient & $0.336 * *$ & $0.549 * *$ & $-.437 * *$ & $0.422 * * *$ & $-.285 *$ & .089 & -0.138 & \multirow[t]{2}{*}{1.00} \\
\hline & Sig & 0.005 & 0.000 & 0.000 & 0.004 & 0.027 & 0.505 & 0.254 & \\
\hline
\end{tabular}

Note : ** Correlation is significant at the 0.01 level (2-tailed).

* Correlation is significant at the 0.05 level (2-tailed). 
The Impact of Equity Incentives on the Accuracy of Analyst's Earning Forecasts

Dr/ Samar Mansour Elsebaai Mohamed Moubarak

Table (7) reports the results of testing the impacts of equity incentive variables OPTION and RSU- on FACC. First results of this table, it is clear that there is a correlation between variables, as there was a relationship between the CEO options and the other variable (accuracy of earning forecast) at the level of significance of $1 \%$. Also results reached to that there is a correlation between the variables of the first hypothesis.

Second Restricted stock units and FACC at the level of significance of $1 \%$, the relationship between them has reached (0.549). The results of this study concluded that there is a correlation between the RSU and FACC at the level of significance of $1 \%$ and level of significance of $5 \%$, where all the relationships between these variables and each other came below the mentioned level of significance. This result is consistent with hypothesis 2 . This mean that RSU provide more FACC than SO, so it can be used as a motivating tool for manager to improve future performance.

\section{Turning to control variables Table (7) can explain the relationship between control variables (earning volatility, firm size, Accounting Loss, absolute earning surprise) on the dependent variable which can summarized as:}

- VOLROA is a control variable, reflecting earning volatility of the listed company, which is measured as the standard deviations of the previous returns to each share. 
The Impact of Equity Incentives on the Accuracy of Analyst's Earning Forecasts

Dr/ Samar Mansour Elsebaai Mohamed Moubarak

There is a negative and significant correlation between Earning volatility and Accuracy of earning forecast at $1 \%$ level of significance, which means that whenever companies care about Earning volatility, this will lead to a decrease in Accuracy of earning forecast where the correlation coefficient between the two variables $(\mathrm{R}=$ 0.437 ).

- There is a positive correlation between both Firm Size and Accuracy of earning forecast at a $1 \%$ level of significance, which means that increasing of Firm Size will increase the Accuracy of earning forecast for companies, and the correlation coefficient between the two variables $(\mathrm{R}=$ 0.422). This means that large firms tend to disclose more information and thus analyst forecasts of large firms exhibit greater forecast accuracy.

- There is a negative correlation between Accounting Loss and Accuracy of earning forecast at a $1 \%$ level of significance, as companies interest in Accounting Loss will be reflected negatively on Accuracy of earning forecast, and the correlation coefficient between the two variables $(R=-0.285)$. This means that negative earnings, if unanticipated, analysts are hard to predict and the forecast accuracy is lower for firms with more negative earnings.

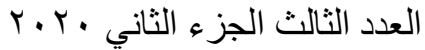

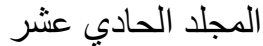


The Impact of Equity Incentives on the Accuracy of Analyst's Earning Forecasts

Dr/ Samar Mansour Elsebaai Mohamed Moubarak

- Results of this study found that there is no relationship between absolute earning surprise and Accuracy of earning forecast, where the significance value was greater than $1 \%$ and greater than 5\%, which indicates the absence of significant.

\section{Hypothesis testing:}

Before performing multiple regression analysis tests, it must first be sure that the necessary conditions are met for the test, and this can be verified through a set of steps as follows:

\section{Table (9)}

Regression results of direct impact of stock options on analysts forecast accuracy

\begin{tabular}{|c|c|c|c|c|c|c|c|c|}
\hline & $\begin{array}{c}\text { Sum of } \\
\text { Squares }\end{array}$ & df & $\begin{array}{c}\text { Mean } \\
\text { squares }\end{array}$ & F. & Sig. & $\mathbf{R}$ & $\mathbf{R}^{\mathbf{2}}$ & $\begin{array}{c}\text { Adjusted } \\
\mathbf{R}^{\mathbf{2}}\end{array}$ \\
\cline { 1 - 4 } Regression & 0.525 & 1 & 0.525 & 8.632 & 0.005 & 0.336 & 0.113 & 0.100 \\
\hline Residual & 4.133 & 68 & 0.061 & & & & & \\
\hline Total & 4.657 & 69 & & & & & & \\
\hline
\end{tabular}

- Through the significance of the model, which has a value less than the level of significance of $5 \%$, it is clear that the hypothesis stipulates that there is a significant effect of the relationship between the two variables, and therefore the regression equation can be formulated in the following image:

$$
\begin{gathered}
\mathrm{FACC}=\mathrm{a}+\boldsymbol{\beta} \mathrm{SO} \\
\mathrm{FACC}=0.176+3.009 \mathrm{SO}
\end{gathered}
$$

r. r. العدد الثالث الجزء الثاني

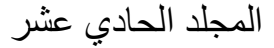


The Impact of Equity Incentives on the Accuracy of Analyst's Earning Forecasts

Dr/ Samar Mansour Elsebaai Mohamed Moubarak

H2: There is a significant impact Restricted stock units on analysts forecast accuracy .

By regression analysis we obtain the results shown in the following table:

Table (10)

Regression results of the impact of restricted stock units on analysts forecast accuracy

\begin{tabular}{|c|c|c|c|c|c|c|c|c|}
\hline & $\begin{array}{c}\text { Sum of } \\
\text { Squares }\end{array}$ & $\mathbf{d f}$ & $\begin{array}{c}\text { Mean } \\
\text { squares }\end{array}$ & F. & Sig. & R & $\mathbf{R}^{2}$ & $\begin{array}{c}\text { Adjusted } \\
\mathbf{R}^{\mathbf{2}}\end{array}$ \\
\hline Regression & 1.403 & 1 & 1.403 & 29.310 & 0.000 & 0.549 & 0.301 & 0.291 \\
\hline Residual & 3.255 & 68 & 0.048 & & & & & \\
\hline Total & 4.657 & 69 & & & & & & \\
\hline
\end{tabular}

- There is a significant impact Restricted stock units on analysts forecast accuracy, and therefore the regression equation can be formulated in the following formula:

$$
\begin{gathered}
\text { FACC }=\mathrm{a}+\boldsymbol{\beta} \text { RSU } \\
\text { FACC }=.356+0.286 \mathrm{RSU}
\end{gathered}
$$

Multiple regression can be used to explain the most independent variables affecting the dependent variable, as follows :

\begin{tabular}{|c|c|c|c|c|c|c|c|c|c|}
\hline & Model & $\begin{array}{c}\text { Mean } \\
\text { squares }\end{array}$ & df & $\begin{array}{l}\text { Sum of } \\
\text { Squares }\end{array}$ & $\mathbf{F}$ & Sig. & $\mathbf{R}$ & $\mathbf{R}^{2}$ & $\begin{array}{c}\text { Adj. } \\
\mathbf{R}^{2}\end{array}$ \\
\hline \multirow[t]{3}{*}{1} & Regression & 1.403 & 1 & 1.403 & \multirow[t]{3}{*}{29.310} & \multirow[t]{3}{*}{0.000} & \multirow[t]{3}{*}{0.549} & \multirow[t]{3}{*}{0.301} & \multirow[t]{3}{*}{0.291} \\
\hline & Residual & 3.255 & 68 & \multirow[t]{2}{*}{.048} & & & & & \\
\hline & Total & 4.657 & 69 & & & & & & \\
\hline \multirow[t]{3}{*}{2} & Regression & 1.716 & 2 & .858 & \multirow[t]{3}{*}{19.548} & \multirow[t]{3}{*}{0.000} & \multirow[t]{3}{*}{0.607} & \multirow[t]{3}{*}{0.368} & \multirow[t]{3}{*}{0.350} \\
\hline & Residual & 2.941 & 67 & \multirow[t]{2}{*}{.044} & & & & & \\
\hline & Total & 4.657 & 69 & & & & & & \\
\hline
\end{tabular}

Table (11) Multiple regression results

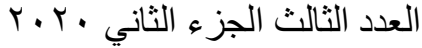

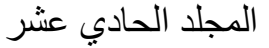


The Impact of Equity Incentives on the Accuracy of Analyst's Earning Forecasts

Dr/ Samar Mansour Elsebaai Mohamed Moubarak

The possibility of formulating a hostile Of multiple regression are the following image:

$$
\begin{gathered}
\mathrm{FACC}=\mathrm{a}+\beta_{1} \mathrm{SO}+\beta_{2} \mathrm{RSU} \\
\mathrm{FACC}=.302+.266 \mathrm{SO}+.457 \mathrm{RSU}
\end{gathered}
$$

Test the effect of control variables on the dependent variable: The effect of the control variables on the dependent variable can be explained as :

\section{Table (12)}

Regression results of Direct impact Earnings volatility on analysts forecast accuracy

\begin{tabular}{|c|c|c|c|c|c|c|c|c|}
\hline & $\begin{array}{c}\text { Sum of } \\
\text { Squares }\end{array}$ & Df & $\begin{array}{c}\text { Mean } \\
\text { squares }\end{array}$ & F. & Sig. & $\mathbf{R}$ & $\mathbf{R}^{2}$ & $\begin{array}{c}\text { Adjusted } \\
\mathbf{R}^{2}\end{array}$ \\
\hline Regression & 0.271 & 1 & 0.271 & 15.941 & 0.000 & -0.437 & 0.191 & 0.177 \\
\hline Residual & 1.150 & 68 & 0.017 & & & & & \\
\hline Total & 1.421 & 69 & & & & & & \\
\hline
\end{tabular}

- As this is evident through the regression equation, which proves that the value of the influence coefficient is negative, as follows :

$$
\begin{gathered}
\text { FACC }=a+\boldsymbol{\beta} \text { VOLROA } \\
\text { FACC }=.154-0.108 \text { VOLROA }
\end{gathered}
$$

\section{Table (13)}

Regression results of Direct impact of Firm Size on analysts forecast accuracy

\begin{tabular}{|c|c|c|c|c|c|c|c|c|}
\hline & $\begin{array}{c}\text { Sum of } \\
\text { Squares }\end{array}$ & df & $\begin{array}{c}\text { Mean } \\
\text { squares }\end{array}$ & F. & Sig. & R & $\mathbf{R}^{2}$ & $\begin{array}{c}\text { Adjusted } \\
\mathbf{R}^{2}\end{array}$ \\
\hline Regression & 0.050 & 1 & 0.050 & 12.501 & 0.004 & 0.422 & 0.178 & 0.159 \\
\cline { 1 - 3 } Residual & 0.231 & 68 & 0.004 & & & & & \\
\hline Total & 0.282 & 69 & & & & & & \\
\hline
\end{tabular}

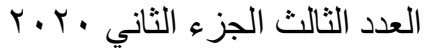


The Impact of Equity Incentives on the Accuracy of Analyst's Earning Forecasts

Dr/ Samar Mansour Elsebaai Mohamed Moubarak

Firm Size has a positive impact on analysts forecast accuracy through the following equation:

\author{
$\mathrm{FACC}=\mathrm{a}+\boldsymbol{\beta}$ Size \\ $\mathrm{FACC}=.152+0.2038$ Size
}

Table (14)

Regression results Direct impact Accounting Loss on

analysts forecast accuracy

\begin{tabular}{|c|c|c|c|c|c|c|c|c|}
\hline & $\begin{array}{c}\text { Sum of } \\
\text { Squares }\end{array}$ & df & $\begin{array}{c}\text { Mean } \\
\text { squares }\end{array}$ & F. & Sig. & $\mathbf{R}$ & $\mathbf{R}^{\mathbf{2}}$ & $\begin{array}{c}\text { Adjusted } \\
\mathbf{R}^{\mathbf{2}}\end{array}$ \\
\hline Regression & 0.116 & 1 & 0.116 & 6.105 & 0.027 & -0.285 & 0.081 & 0.066 \\
\cline { 1 - 3 } Residual & 1.305 & 68 & 0.019 & & & & & \\
\hline Total & 1.421 & 69 & & & & & & \\
\hline
\end{tabular}

\title{
The following table shows the following:
}

it is possible to judge acceptance For a relationship between the two variables, the influence factors can be illustrated by the following equation:

$$
\begin{gathered}
\mathrm{FACC}=\mathrm{a}+\boldsymbol{\beta} \text { LOSS } \\
\mathrm{FACC}=.264-0.013 \text { LOSS }
\end{gathered}
$$

\section{Table (15)}

Regression results of Direct impact Absolute earning surprise on analysts forecast accuracy

\begin{tabular}{|c|c|c|c|c|c|c|c|c|}
\hline & $\begin{array}{c}\text { Sum of } \\
\text { Squares }\end{array}$ & df & $\begin{array}{c}\text { Mean } \\
\text { squares }\end{array}$ & F. & Sig. & $\mathbf{R}$ & $\mathbf{R}^{2}$ & $\begin{array}{c}\text { Adjusted } \\
\mathbf{R}^{\mathbf{2}}\end{array}$ \\
\hline Regression & 0.017 & 1 & 0.017 & .548 & 0.504 & 0.089 & 0.008 & -0.010 \\
\cline { 1 - 3 } Residual & 2.068 & 68 & 0.031 & & & & & \\
\hline Total & 2.085 & 69 & & & & & \\
\hline
\end{tabular}

العدد الثالث الجزء الثاني • r r r

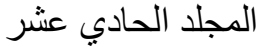


The Impact of Equity Incentives on the Accuracy of Analyst's Earning Forecasts

Dr/ Samar Mansour Elsebaai Mohamed Moubarak

The results concluded that there was no significance for the regression model to measure Absolute earning surprise on analysts forecast accuracy, because the significance value of the model was greater than 5\%, which means rejecting the relationship between the two variables.

\section{Table (16)}

Regression results of Direct impact Dispersion on analysts forecast accuracy

\begin{tabular}{|c|c|c|c|c|c|c|c|c|}
\hline & $\begin{array}{c}\text { Sum of } \\
\text { Squares }\end{array}$ & $\mathbf{d f}$ & $\begin{array}{c}\text { Mean } \\
\text { squares }\end{array}$ & F. & Sig. & $\mathbf{R}$ & $\mathbf{R}^{\mathbf{2}}$ & $\begin{array}{c}\text { Adjusted } \\
\mathbf{R}^{\mathbf{2}}\end{array}$ \\
\hline Regression & 0.089 & 1 & 0.089 & 1.323 & .254 & 0.138 & 0.019 & 0.005 \\
\cline { 1 - 4 } Residual & 4.569 & 68 & 0.067 & & & & & \\
\hline Total & 4.657 & 69 & & & & & & \\
\hline
\end{tabular}

The results concluded that there was no significance for the regression model to measure Depression on analysts forecast accuracy, because the model's significance value was greater than $5 \%$, which means rejecting the relationship between the two variables.

\section{Summary and conclusions:}

This study examines the relationship between equity incentive plans and the accuracy of analysts' earnings forecasts , specifically it examine the how the analysts accuracy can be affected by compensating managers with incentives in the form of stock options and restricted stock units..

$$
\text { r. r. • العدد الثالث الجزء الثاني }
$$$$
\text { المجلد الحادي عشر }
$$ 
The Impact of Equity Incentives on the Accuracy of Analyst's Earning Forecasts

Dr/ Samar Mansour Elsebaai Mohamed Moubarak

This study differs from these studies as it combines between two types of equity incentives (stock options and restricted stock units) and provides the differential effects on the forecast accuracy. Results found that restricted stock provide more accuracy than options. Additionally it investigates how the forecast accuracy can affect on their stock recommendations. First, this study hypothesizes that CEO who compensated with stock options can affect on forecast accuracy. On the examination of this hypothesis in this study results find that Pearson Correlation is 0.336 , which means there is positive association between managers who compensated with stock options and earnings forecast accuracy as this type of compensation improve disclosure environment by better aligning between managers and shareholders' interests.

This results matching with some prior study such as

Second: an examination of the second hypothesis the findings show that P.Correlation $=0.549$. These results ensure that there is a positive association between managers who compensated with restricted stock units and analysts forecast accuracy. Results of this study also show that restricted stock units provide more accuracy of financial analyst's forecasts than stock options, so stock options become less attractive to managers.

$$
\text { r. r. • العدد الثالث الجزء الثاني }
$$


The Impact of Equity Incentives on the Accuracy of Analyst's Earning Forecasts

Dr/ Samar Mansour Elsebaai Mohamed Moubarak

\section{REFERENCES}

1. Abudy, M., and Benninga, S., (2016). Valuing restricted stock grants to non-executive employees. Journal of Economics and Business, vol.86, PP.33-51.

2. Choi, B., and Kim, J., (2016).The Effect of CEO Stock-Based Compensation on the Pricing of Future Earnings. European Accounting Review, pp.1-30

3. Fang, H., et al., (2015). The effects of employee stock option plans on operating performance in Chinese firms. Journal of Banking \& Finance, vol.54, pp.141-159.

4. Han, S., et al., ( 2014). Managerial Ownership and Financial Analysts' Information Environment, Journal of Business Finance \& Accounting, 41(3) \& (4), 328-362.

5. Jiang, L., et al., (2017). Why do firms adopt stock options and who benefits? A natural experiment in China. Pacific-Basin Finance Journal (46), pp.124-140.

6. Liu, S., (2018). The impact of equity incentive plans on analysts' earnings forecasts and stock recommendations for Chinese listed firms: An empirical study. Journal of International Accounting, Auditing and Taxation, PP.1-38.

\section{Books:}

1- Langkos, S (2014), RESEARCH METHODOLOGY: Data collection method and Research tools, University of Derby.

2- Saunders, M., et al., (2012). Research methods for business students, Pearson Education. Haelow, UK.

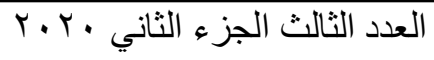

